\title{
Enrichment in Teaching in Classroom and Better Management in Examinations: methods for Teachers
}

\author{
Md Harunur Rashid \\ Assistant Professor, BCS (Education) Directorate of Secondary and Higher Education, Dhaka. \\ Govt. Republic of Bangladesh. (M. Phil Researcher, University Of Dhaka, Bangladesh)
}

\begin{abstract}
Teachers, who are the steersmen of education. So the ideology of a good teacher will be reflected in a worthy nation. There is no alternative to make a world class teacher for spreading ourselves worldwide as well as to develop the standard of the nation. A poor nation remains poor in the standard of knowledge as long as it is run by improper teaching of incompetent teachers in the insincere, hollow society. Excellency in brilliance alone is not a standard to justify teachers. The talented persons will be capable of being the good teachers when they are properly trained up. It is to be noted, a teacher who attains complete control and success in his class not for gaining success in theoretical academic exams, can be considered as a real, worthy teacher for teaching profession. Only then quality education will be ensured. For this reason, some inevitable abilities of teaching such as dramatic start, moderate voice, rational analysis ability, capability of socialization, temperate eloquence, sense of humor, sense of proper time management, power of making the topic attractive and devotion and commitment towards the profession are to be ensured. Financial security and social dignity can only encourage the meritorious for teaching but never can assure a competent teacher. An eligible teacher must have sincerity and commitment to the profession. In this regard, effective practical training and experiment is a must. In this article, we are going to discuss the issues that are apparently unnecessary but actually very essential in relation to scarcity of competent teachers.
\end{abstract}

\section{Introduction}

The teachers who do not take the teaching profession of their own, fail to teach the students properly and to do other activities and obviously who take this profession sincerely are the successful ones. The fact is that in a corrupted country, teaching profession is not a prestigious job. Because there is no so much scope for corruption in teaching as it is in bureaucracy. So teachers are not financially solvent. This profession becomes the last option of a person. But to build up a truly educated nation, the most meritorious students should be the teachers. Without competent teachers, teaching will not be succeeded. Rabindranath Tagore once said "It is the teachers, who teach; not the system." ${ }^{\prime 1}$ It is said in the International commission for Education in the $21^{\text {st }}$ century that competent teachers are required for better education. ${ }^{2}$ At present, textbooks are given more importance than the betterment of teachers in "Education Policy"3. For the want of competent teachers is the main reason of misery in education system. Kazi Motaher Hossain felt that and said, "The mental growth of our students is being hampered under the supervision of ignored and poverty stricken teachers. They are getting biased and bookish instead of soling real problems." ${ }^{4}$ Incompetent persons create extreme chaos when they come in teaching profession. They are not able to take decision about administration. So those people who are not related to teaching take over the control. And education system has to suffer from wrong decision. As a result, the state faces extreme anarchy.

\section{Techniques for Teachers to be Successful in Class Management \& Teaching} 1.1. Love and Commitment towards the Profession:

Firstly, a teacher should have commitment and devotion for teaching. A good teacher should be determined. In "The Art of Teaching" Gilbert Highet said, "A teacher who dislikes or is disinterested in his subject, is a kind of traitor". When a teacher loves his subject, he can find pure joy during teaching in a class even then he is very tired and exhausted. But poverty is the main obstacle in loving teaching profession. A teacher's salary is as few as a day-laborer's wage. Yet his lifestyle is different from a laborer's lifestyle. Despite of poverty, many teachers can uphold their nobility.

\subsection{Make the lesson Easy to Understand:}

The recitation of a topic from textbook uninterestingly does not help the students. Discovering the real meaning of lesson to the students is the main duty of a teacher. He has to create a relationship between the students and the text. Teachers should make the lesson suitable for mediocre students. 


\subsection{Fluency Skill:}

Once an orator was asked, "which skills are important for public speech?" He answered, "Firstly, Technique of speech; secondly, technique of speech and thirdly, technique of speech." ${ }^{\prime 6}$ But some teachers just recite the whole topic in a monotonous tone like each word has same importance. This kind of speech never attracts the students. For example, when a teacher teaches the fine art, he should have knowledge about design, abstraction, elegance and enrichment of fine art. But when he ignores these, actually he loses the chance of teaching much more than the theory and information. A successful speech depends on rice and body language to a great extent. So, one has to acquire the art of speech. He has to practice the modulation of voice, training on correct pronunciation. Moreover, in teaching profession, use of a flawlessly passionate voice is most necessary. Many people think that in student life, participating in debate or recitation or singing causes harm in study. But that clubbable fellow becomes leader in professional life. They can represent themselves, their thoughts and ideas in the best way. These skilled, fluent and expert persons are acceptable to anyone very easily.

\subsection{Use of Teaching Aid Element:}

First of all, teachers need proper training for this. But before that we need a research on how the conventional training program helps teachers to be the expert ones. So, a teacher has to make own self. He has to use teaching aid elements for that. Now-a-days, it is possible to show all elements of lesson by using digital multimedia and projector. If a teacher makes the students interested about topic, the lesson will be successful.

\subsection{Acting skill:}

Everyone likes watching an actor. It helps to learn also. So, when your teacher tries to teach your lesson by acting or his body language, you get an easy access to the depth of the topic. But most of the time, our teachers are like statue. So his monotonous, boring speech can not attract the students. But a teacher, who has a better acting skill, can easily take the students to an imaginary world with his hypnotizing power. Students will not be bored with long duration of class.

\subsection{Topic related knowledge:}

The first and foremost quality of an ideal teacher is having vast knowledge and updated information about his subject. If any student is very good at chemistry, then the teacher should be capable of inspiring him. Each ideal teacher updates his knowledge in every year, every month and if possible in every week. Most of the teachers have idea about his subject, but he has to point out the most exciting and interesting topic. Then he will add real example and make it attractive. So the students become curious about it. Teachers will have idea about not only text books but also reference books. Reference books contain the background of the topic which will amaze the students.

\subsection{Dramatic Start:}

A teacher should understand that study is boring to every student. The starting should be interesting and dramatic, so that students can not realize that it has begun. At the beginning, the real story related to be text; then the actual topic of textbook. Many teachers think some subjects like mathematics, science can not be taught in this way. But this concept is not true at all. There are many applications of mathematical formulas in real life which can be easily shown in the class.

\subsection{Sense of Humor and Renovating skill:}

A teacher should be a source of teachable sense of humor. The course might be uninteresting and hard to realize. But a good teacher can renovate the course and make it interesting. Kazi Motaher Hossain said:

"The nations who can enjoy without limit, who are not coward, doubtful or in hesitation; they are full of life, independent and powerful. Their life is full of joy in everywhere. There will be glory and inspiration in every activity. The talent will bear in that society wherein joy and humor prevail.,"7 A teacher slowly brings up the complex part of the text from the story. He will enlighten the subconscious mind of a student with his humor. But that humor must conduct with the main theme of the text. He will exchange own experience with students. The more the text is complex, the more it will be part by part.

\subsection{Speed of Lecture and Mannerism:}

It is also noticeable that how quickly a teacher speaks. First few minutes of a class there is noise and indiscipline. So then, teacher should speak slowly but emphasize on words. The speed will increase by the course of time. He should deliver his lecture in various tones. He will emphasize on the key words and important chapter and read them slowly. He will read out the less important topic in a regular tone. That variety will help the students to realize the importance of the chapter. If there is any funny topic, then you have to give chance to laugh at that extent. Rather they will miss the lecture. Many teachers speak in their local dialects. 
Some of them have peculiar habits. Like as some teachers utter meaningless words like "hmm", "ok", "Understand" etc. This is very boring. It must be avoided. He can help himself by recording one lecture and then work out with the problems.

\subsection{Harmony between syllabus and Schedule Time:}

It is often happened that teachers notice the syllabus yet not completed but the exam is at door or they try to complete the 50 minute- lecture in 15 minutes. This really hampers the unlucky students. So a good teacher must have a good teaching plan. He will maintain a schedule. According to that he will make a plan of lessons and number of classes. If he has a chance to take some classes again and again, then he will get an idea about that. Besides, sometimes they can not manage the schedule. Many teachers spend time in talking to someone personally which is never acceptable. He should give equal importance to all and his all speech should be applicable for all. And the students will also have to be conscious that their question should be useful for all students and text related. Teacher should not stay in class after the scheduled routine. Students don't like to listen to you after class period. So if you continue your lecture, then it will go in vain. If there is a special case, make the students aware about it before class-ending. Rather, whether it is important or the syllabus is long, you should never make them wait.

\subsection{Evaluation on Mentality and Reaction of the Students:}

A teacher must be aware of his student's age. Secondary teaching method varies from the teaching method of higher education. Students of secondary level are more unsteady and they become thrilled with joy for a trivial matter. Problem-solution method is useful to keep them attentive and active in class. But students of higher level are more experienced and steady. They don't get thrilled easily. At this stage, students like the thoughtful topics and they evaluate the depth of knowledge of the professor. Teachers should notice the reaction of his pupils. He will point out that topic which is interesting to topic. He should avoid the topics which make them annoyed.

\subsection{Participation of the Students:}

It is easy to deliver an ordinary lecture. But it is really tough to make it attractive and interesting. And it is a must to create decency and loveliness in class lecture Gilbert Murray never spoke a word rudely. He never used meaningless words such as "hmm", "aah" etc. His presentation method was excellent. And thus the students felt full concentrated in text problems. A teacher will observe the text topic impartially. He should not give any partial opinion about the topic. He will ask the students for their opinions. Then he will discuss the merits and demerits of their opinions. If necessary, he can divide them into some small groups for discussion. Above all, students should be closely intimated with any topic.

\subsection{A question-answer session; comment from students:}

A teacher does not give a lecture only in this method. The best example of this method is the tutorial system of Socrates. Here a teacher gives a question or a problem and students try to answer by discussion. Question after question helps them to realize the truth. Then they believe in this truth deeply. This question answer method creates an internal reaction among the students. They feel interested when their answer is being given importance. But some indiscipline students try to make fun about the question. Teachers will warn them strictly. He will make them know it is not the way to be a hero or center of attraction. For that, they have to cut a good figure in examination.

\subsection{To find out the Indiscipline Student and warning specifically:}

Sometimes, teachers say- "Some students are never meant to be loved." It's true; sometime a teacher has to control a group of naughty boys. We can remind of Keats. When he was the principal of a renowned school named Eton of Britain, the most indiscipline student also felt hesitation in front of him. But now in New York at some schools, to protect teachers, they need police watch. This is really a serious issue. But it's not a central problem. It happens in a few institutions. So to solve this kind of problems, teacher should follow the psychological technique and sympathy. Gilber Highet advised to appoint male teachers in this institution rather than female teachers. ${ }^{8}$ Most of the time students like to obey male teachers. Lack of techniques of a teacher is mainly responsible for indiscipline and noise in a classroom. Many teachers waste time by saying "No talk", "silent" etc randomly. In that case, students feel that teacher could not point them out, who are making noise. They continue to talk to each other. This increases the noise and chaos. During the lecture, a teacher has to point out the particular student who is making noise. Then punish that student in accordance with his/her age. The teacher can make him stand up and ask a question from text. If he can not answer, keep him standing. It will keep others silent. But for a student of secondary level, you can punish him in other ways such as "Write the sentence 'I won't talk anymore' many times". For a higher level student, few harsh words are enough. Punishment for one makes others silent. But physical punishment is never acceptable. 


\subsection{Proper Idea about Classroom (Position, sound system, temperature etc):}

Generally the place in front of the blackboard is fixed for teachers. But he can use any other blank space for his teaching purpose. He should stand in such a corner, so that he can have an overall view of the classroom. Not a particular direction, teacher should look at the eye of each student. He should notice the sound system, so that everyone can listen to him properly. At the beginning of class he should check that fan/AC for temperature control is okay. Students prefer to sit at the back bench in the classroom. The teacher will make them to sit at the first bench or in middle. If the microphone is to keep in hand, then he should keep it in one inch away from mouth. If there are other problems or limitations in classroom, the teacher will notice those and share with students. Rather students will think that their teacher is unaware of problems.

\subsection{Emphasize on Overall problem:}

Sometimes, students try to talk about their personal problems in class period such as attendance issue, absence in tutorial etc. But this practice is not good. For this type of personal problem they should come to office at leisure period or after class. Class period is only for those problems which is applicable for all.

\subsection{Teaching Evaluation:}

This is a good process to measure your success of teaching. Last five minutes of class period should be reserved for this. The teacher will ask questions based on the lesson of that day. If most of the students give right answer, then teaching is successful.

\subsection{Preparation for Conducting Examination:}

The first duty is to prepare the question paper at least in the previous day. So the teacher should have instructions about the timing. There should be enough time left for typing, printing and correction. At the examination day, question paper should be kept in examination control room. Before 30 minutes of starting time of exams, these should be distributed according to seat plan in class room. Teachers should enter the examination hall before 10-15 minutes. Two or three teachers should be reserved; if any assigned teacher is absent, then they can perform the duty.

\subsection{Strict warning for students:}

After giving the answer paper to students, teacher will provide them necessary instructions, so that students can fill up all the information properly. Before giving the question paper, he will warn them very strictly about unfair means in examinations. As a result, conducting the examination will be easier.

\subsection{Exact starting of Examinations:}

If there is more than one invigilator, then it is easier to give away question papers. But when only one invigilator is available he should give the question papers to the first one and say him to keep one and pass others to the next one. Some indiscipline students should be given strict instructions to keep silence at the beginning of examination.

\subsection{Invigilate the full Examination Hall:}

Some teachers give attention to few students. They try to talk to their preferable students. This creates chaos in examination hall. Teachers should invigilate the whole examination hall and find out the particular student like "Stand up him for 5 minutes"; "Cease the answer paper for 5 minutes," or "cutting 5 marks". This punishment of one student warns all the examinees.

\subsection{Carefulness about Signing on Answer Paper:}

Signing the answer papers is one of the main duties. But for this some teachers want special facilities. They can not sign without sitting erectly. But this gives the students chance to talk. So teachers should be habituated in signing the papers on hand like the journalists. It will help him to invigilate simultaneously. In result, discipline will be maintained.

\subsection{Maintain the Total Discipline:}

Sometimes, a teacher keeps himself busy in punishing one student. Then other students make noise. Moreover, many teachers talk among themselves. Students take this chance to talk to each other. So teachers should keep silence also in examination hall. Sometimes teachers make more noise when they try to control. But they should control students without making noise. 


\subsection{Eye contact with Students:}

Teachers will keep eye contact with students. So students will get no chance of watching others' papers. If anyone tries to do this, teacher will punish that student immediately.

\subsection{No sauntering unnecessarily:}

Some teachers saunter in examination hall without any reason. When teachers look behind, students make noise. Even they show answers by finger in case of objective examination.

\subsection{Observing in Standing Position:}

Teachers should observe the students by standing in a convenient corner, so that he can observe all the students at a time and maintain proper discipline.

\subsection{Punish individually; not all:}

According to the rules, a teacher will punish those students who are really responsible for noise. But some teachers yell at all which makes it worse.

\section{Conclusion}

In fact, quality education is necessary for the prosperity of a nation or a country. But in developing country, education system is hackneyed and dependent on memorizing. Want of competent teachers is one of the main reasons for this problem. Bangladesh Government signed in the "Delhi Declaration 1993". That says "We will improve the standard and relevance of basic education program. And for this we will emphasize on improving teacher's training program, honor and financial solvency." "So increasing salary and bonus is not enough for appointing and continuing competent teachers; improvement of social respect is also necessary. Bangladesh "National Education Policy, 2010" advises "For increasing the financial facilities separate salary scale will be prepared for the teachers of all level and medium." ${ }^{10}$ We should acknowledge that teaching method of a teacher in classroom determine the standard of education of a country. We should consider the thought of renowned educationist Kazi Mothar Hossain:

Good students can be good teachers. So government can find out the meritorious student who has done extra-ordinary result in matriculation exam (at present SSC). Then they should be given proper education and maintenance support to make enough number of teachers, doctors, engineers, lawyers, agriculturists, ambassadors as per the demand of country. ${ }^{11}$

\section{References:}

[1]. Oitiyo, Rabindra Rachanabali, (Vol.16, Dhaka, 2004). (324)

[2]. Jack Delor, Shikhon: Antarnihito Shampod, (UNESCO, Dhaka, 1996). (86)

[3]. Ministry of Education,( Education Policy-2010), (Bangladesh, 2010).(18)

[4]. Abdul Huq (Editor), Kazi Motahar Hossain Rachanabali, (Vol.2, Dhaka, 1986). (24)

[5]. Prof. M. Hossain, Gilbert Highet -The Art Of Teaching, ( Dhaka, 2009). (25)

[6]. Prof. M. Hossain, Gilbert Highet -The Art Of Teaching,( Dhaka, 2009).(78)

[7]. Abdul Huq (Editor), Kazi Motahar Hossain Rachanabali, (Vol.2, Dhaka, 1986). (48)

[8]. Prof. M. Hossain, Gilbert Highet -The Art Of Teaching, ( Dhaka, 2009). (33)

[9]. Abdul Malek and others (2007), Science of Education in Bangladesh. (Vol.2 (University Grant Commission, Bangladesh.2007). (459)

[10]. Ministry of Education,( Education Policy-2010), (Bangladesh, 2010).(34)

[11]. Abdul Malek and others (2007), Science of Education in Bangladesh. (Vol.2 (University Grant Commission, Bangladesh.2007)(24) 